\title{
The Integration of Life and Ideological Education
}

\author{
Daoxun Wang \\ Huanghe Science and Technology College \\ Zhengzhou, China
}

\begin{abstract}
The ultimate goal of life, ideological and political education is to reveal the meaning of life. In periods of social transition, there is a pressing need to improve our analysis of the ideological, psychological and behavioral conditions of college students. The traditional approach to ideological and political education requires modernization of both its content and form, so as to more effectively integrate science and life education. This will require an entirely new model.
\end{abstract}

Keywords-Life education; Iintegration; Ideological Education System

\section{INTRODUCTION}

At present, China is in a period of social transformation, rapid economic development and lifestyle change. On account of this, students are faced with great opportunities for development, but also enormous challenges. Some of the students fall into confusion and complexity with regards to how they are to deal with life's various problems. In recent years, there has been a significant increase in instances of dishonesty, violence, cruelty to animals, and homicide, committed by college students. It would seem that students with an apparent lack of social and moral responsibility are becoming a more common occurrence. Likewise, the proportion of students with psychological illness has risen year by year. The key objective of ideological and political education is to solve the problems identified though an objective analysis of the ideological, psychological and behavioral conditions of the present age.

The ultimate goal of this integrated education, is to highlight the significance of human life. Therefore, an entirely new moral is required. The traditional approach to ideological and political education requires modernization of both its content and form, so as to more effectively integrate science and life education.

\section{THE CURRENT STATUS OF IDEOLOGICAL AND POLITICAL EDUCATION AND ITS INADEQUACIES}

\section{A. Ideological, Moral, Psychological Status Quo of College Students}

Today's college students are effected by a distinct social environment to that of their predecessors, which has led to a dramatic shift in their values, ethics and behaviors. In this period of rapid growth and development, students present many new features. They a more passionate, daring, unconventional, knowledgeable and have attained a level of individuality unmatched by previous generations. But alongside these positive traits, they have been influenced by a number of unhealthy social behaviors, for example, it is regarded as normal and acceptable by this generation of College students to cheat on exams. Likewise, they demonstrate indifference, and a lack of empathy towards others, as well as being prone to interpersonal discord. In public places, they do not pay attention to etiquette or manners. In addition, a poor ability to cope with frustration has led to an increased rate of suicide and other harmful behaviors. Assessments of the 90s generations vary greatly, however one major strand of thought considers them to worryingly 'divergent', and remains concerned that this generation may be unable to smoothly assume their social and historical responsibilities.

The characteristics of each generation are but a reflection of the conditions of the time. Evaluations of this generation of students should endeavor to be objective and comprehensive and, in the same turn, resist the urge to merely belittle or to complain. The most important questions is how are we to guide them.

\section{B. The Relationship Between Life, Ideological and Political Education}

The purpose of life education is to teach respect for life. It hopes to create the conditions which promote the full and harmonious life and healthy development. Ideological and political education seeks to promote the ideas, political views, and ethics of a particular social community and apply them, in accordance with the purpose of the group's members, to establish their influence and thereby form a social practices in line with moral character of said community.

Broadly speaking, ideological and political education already includes life education. Or otherwise put, life education and mental health education is an important part of the ideological and political education. In fact, the ideology, politics, world view, philosophy, values, ethics, legal sense, life concept and mental health, of college students', all fall under the scope of political education. Although in many ways life education differs in content from that of ideological or political education, they are inextricably linked. In essence, they both serve to foster the development of a comprehensive human purpose. While there is only some overlap between the content taught by each subject, their methods complement one another. Ideological and political education influences and shapes the moral character of students, this in turn has a positive impact upon their psychological conditions, improving their mental stability and wellbeing. In practice, life education is taught within 
ideological and political education. Ideological and political education also involves a great deal of mental health education, and goes further to address issues not given full attention in this field of study such as: bioethical issues; death; and the relationship between life, society and the environment; and leisure and health education.

Therefore, the two disciplines always intersect, mutually penetrate, complement, and mutually reinforce one another. Together they play a role in the process of educating students so they may establish themselves, and others, create an environment of mutual respect, and ultimately enjoy a mature and happy life.

\section{The Integration of Life, Ideological and Political Education}

In order to integrate college life education with ideological and political education, you first need educators to understand the integrated nature of these disciplines. Educators should deeply understand the importance of strengthening ideological and political education, and know the characteristics of the current ideological and political education; its status, requirements and tasks. Once fully aware of the relationship between the two, they will understand that that psychological wellbeing is the psychological basis for the formation of good moral character and good moral character is an important prerequisite for good mental health. Indeed, Life education is both the start and the end of political and ideological education.

Life education is new type of education which takes life as its starting point, focuses on the development of life on to its completion, in order to enhance the quality of one's life and make it more meaningful. It considers the educational process to be one with the process of growing human life, fulfilling it, balancing its development and growth, in the constant pursuit of the meaning of life. Ideological and political education has, "comprehensive development of students as the goal." Both, then, have a common educational purposes, but the focus is different. Both goals should be integrated, summed up in a general goal: a new type of socialism, inspiring a new type school, in which students are trained comprehensively and so enjoy a healthy development.

The proper outlook on life and values is the most fundamental content of ideological and political education. These requirements are extremely elaborate and abstract, and rarely touch upon the actual dangers one is likely to encounter in the course of one's life. In real life, college student's ideological problems and psychological issues are very much intertwined. Likewise, the quality, ideals and beliefs of college students are not merely the content of mental health education, but should also be the content of ideological and political education. Therefore, the required content of ideological and political education must be specific, should include the specific content of life education, and sue different ways to penetrate into the ideological and political ideas.

\section{CONCLUSION}

Teachers currently engaged in ideological and political education in the college include: ideological and political theory courses full-time teachers; counselors; College Administrative staff; teachers and other professional psychological counseling. Overall, most educators in ideological and political studies have not systematically studied psychology, and lack the most basic knowledge. Neither have they participated in professional mental health training, and therefore cannot truly understand the psychological dynamics of their students, or effectively employ psychological principles and techniques to solve their psychological distress. On the other side, there are many counselors from the medical profession or other professional graduate teachers, whom lack the theoretical basis of Marxism to engage in political or ideological education. Therefore, universities need to set up mixed talent groups, who can develop both ideological and political work to understand the law, and master certain skills in mental health education. This is the key to improving ideological and political education in a timely manner.

\section{REFERENCES}

[1] Single Chang Yan, Wang Junguang. Life Education and the Construction of College Mental Health Education. Inner Mongolia Normal University (Education Science Edition) .2009.

[2] Xu Xiaohui. Research on ideological and political education and mental health education combined pathway [J]. Theorists, 2008 (2): 186.

[3] Fan Mika. College students' psychological health education and ideological and political education to explore the relationship between [J]. EDUCATION, 2007 (1).

[4] Wu Weiwei. Important moral dimension of university life education [J], China Higher Education Research, 2007 (6).

[5] Chen Wenbin, Liu Jingwei student Life Education [J], China Higher Education Research, 2006 (9).

[6] Country before party. Life Care Education imperative: Ideological new subject Education [J], Renda, 2006 (02). 